\title{
ЕЛЕКТРОТЕХНІЧНІ КОМЛЕКСИ
}

УДК 620.179.14

DOI: https://doi.org/10.32515/2664-262X.2019.2(33).122-129

В.Б. Бондаренко, асп., К.Г. Петрова, доц., канд. техн. наук, С.В. Серебренніков, проф., канд. техн. наук

Центральноукраӥнський нащіональний технічний університет, м. Кропивнищький,

Україна

e-mail: kateflash27@gmail.com

\section{Синтез електромагнітної системи діагностування дефектів опор повітряних ЛЕП із використанням нейро-нечіткого моделювання}

Показано, що за умов невизначеності під час діагностування дефектів опор повітряних ЛЕП в режимі реального часу, раціональним є побудова електромагнітної системи із використанням нейронечіткого моделювання. Розглянуто найінформативніші детерміновані та ймовірнісні ознаки образу дефекту. Доведено, що застосування гібридних нейронних мереж призводить до істотного збільшення швидкодії вихрострумового контролю та надійності розпізнавання дефектів.

дефекти опор, вихрострумовий контроль, нейро-нечітке моделювання, діагностування

В.Б. Бондаренко, асп., Е.Г. Петрова, доц., канд. техн. наук, С.В. Серебренников, проф., канд. техн. наук

Центральноукраинский национальный технический университет, г. Кропивницкий, Украина

Синтез электромагнитной системы диагностирования дефектов опор воздушных ЛЭП с использованием нейро-нечеткого моделирования

Показано, что в условиях неопределенности при диагностировании дефектов опор воздушных ЛЭП в режиме реального времени, рациональным является построение электромагнитной системы с использованием нейро-нечеткого моделирования. Рассмотрены наиболее информативные детерминированые и вероятностные признаки образа дефекта. Доказано, что применение гибридных нейронных сетей приводит к существенному увеличению быстродействия вихретокового контроля и надежности распознавания дефектов.

дефекты опор, вихретоковый контроль, нейро-нечеткое моделирование, диагностика

Постановка проблеми. Останнім часом спостерігається інтенсивне зростання кількості аварійних ситуацій у розподільчих електричних мережах України. Аналізування причин аварій елементів ЛЕП свідчить, що $30 \ldots 35 \%$ становлять пошкодження залізобетонних опор [1]. Це обумовлено тривалою експлуатацією більшості залізобетонних опор понад 20 років.

Для ЛЕП напругою до 10 кВ застосовують опори 3 вібробетону найрізноманітніших перерізів: круглі, гратчасті, прямокутні, порожнисті, суцільні, таврові тощо. Для ліній електропередачі напругою 35-500 кВ найпоширенішими $є$ залізобетонні центрифуговані опори циліндричної або конічної форми (рис. 1). Арматурний каркас таких опор складають поздовжні стрижні, діаметром 12-14 мм (сталь 25 ГС), приварених до внутрішніх монтажних кілець 3 холоднотягнутого дроту діаметром 4-5 мм. Товщина залізобетонного кільця дорівнює 40-60 мм. У нових конструкціях передбачена попередня напруга арматури: шість арматурних стрижнів діаметром 12 мм, що проходять по довжині усього ствола, напружують силою близько

(C) В.Б. Бондаренко, К.Г. Петрова, С.В. Серебренніков, 2019 
40 т; інші - не напружувані 30 стрижнів, обриваються на висоті 4 м від основи опори, на висоті 5,5 м - 27 стрижнів, а на висоті 15 м - всього 10 стрижнів. Стійки опор конічної форми: діаметр в основі 560 мм, у вершині - 334 мм, конусність 1/100.

Опори ЛЕП постійно підпадають під вплив деструктивних процесів, зокрема: атмосферних навантажень, ожеледі, коливань температури, вібрації від вітрових навантажень, дії мінералізованої вологи, хімічно активних речовин, грунтових солей тощо. Це пришвидшує втому й корозійне зношення металу, знижує механічну міцність опор. Агресивне середовище також роз'їдає бетон опори - він втрачає міцність й відшаровується, у місцях контакту 3 окисленою арматурою бетон набухає та утворюються раковини і наскрізні отвори (рис. 1 г); пошкодження захисного шару бетону відкриває додаткові шляхи волозі до армуючих сталевих стрижнів.

Тріщини в арматурі утворюються внаслідок періодичних вигинаючих деформацій опор під дією асиметричних атмосферних навантажень; критичне накопичення дефектів й втрата механічної міцності призводить до падіння опор (рис. 1 д, е). Візуальне виявлення дефектів під шаром бетону, фарби або іншого непрозорого покриття $\epsilon$ недоступним. Інтерпретація результатів неруйнівного контролю й оцінювання критичності дефектів в умовах невизначеності $\epsilon$ проблематичними та вимагає використання інтелектуальних методів діагностування.

Аналіз останніх досліджень i публікацій. До неруйнівних методів діагностування стану арматури та несучої спроможності конструкцій залізобетонних опор ЛЕП належать [2]:

- електрохімічний поляризаційний метод, недоліком якого $\epsilon$ низька достовірність у разі значного ступеню корозії арматури;

- вібраційний метод, недоліком якого $€$ складність створення коливань необхідної інтенсивності;

- ультразвуковий метод, що вимагає створення щільного контакту давача 3 об'єктом;

- метод резонансної частоти, однак резонансна частота та амплітуда великою мірою залежить від демпфуючих властивостей матеріалу навколо арматури;

- рентгенівський контроль є точним, але малопродуктивним і небезпечним тощо.

Це актуалізує удосконалення безконтактного, простого в реалізації електромагнітного методу контролю [2-4], здатного поєднуватися з автоматизованими інтелектуальними системами інтерпретації результатів обстежень.

Постановка завдання. Метою роботи $є$ розроблення системи діагностування дефектів (пошкоджень арматури) опор повітряних ЛЕП на основі поєднання принципів електромагнітного контролю 3 інтерпретацією результатів діагностування iз використанням нейро-нечіткого моделювання.

Виклад основного матеріалу. На рис. 1 показано зовнішній вигляд досліджуваного об'єкта. Для реалізації електромагнітного методу необхідно обгрунтувати тип первинного електромагнітного перетворювача, частоту зондування, схему та алгоритм оброблення сигналу вторинним аналого-цифровим перетворювачем. У випадку використання динамічного режиму контролю крок сканування обирають таким, щоб забезпечити виявлення довільно орієнтованого тріщиноподібного дефекту.

Практика показує, що на стрижнях арматури опор ЛЕП злами орієнтовані перпендикулярно утворюючій, а стрес-корозійні тріщини - паралельно їй. Оптимальні результати електромагнітного контролю досягаються за напрямку сканування, що перетинає дефекти перпендикулярно їх довгій стороні [3]. У разі електромагнітного діагностування висновок щодо наявності дефекту та його розмірів зазвичай грунтується на значеннях амплітуди, фази й частоти поточного сигналу. Проте, завеликі обсяги 
інформації, яка надходять під час контролю десятків й сотен опор ЛЕП у польових умовах під напругою, перевищує можливості людини адекватно іiі сприймати в режимі реального часу та вимагає автоматизації аналізу даних; це істотно збільшить швидкість контролю, зменшить помилки та похибки, пов'язані з діями персоналу, дозволить координатно "прив'язати" результати до об'єкту контролю. За таких умов раціональним $є$ синтезувати електромагнітну систему діагностування дефектів опор повітряних ЛЕП із використанням нейро-нечіткого моделювання. Тобто, створити нейронну мережу та навчити іiї здійснювати пошук дефектів на основі реальних даних.

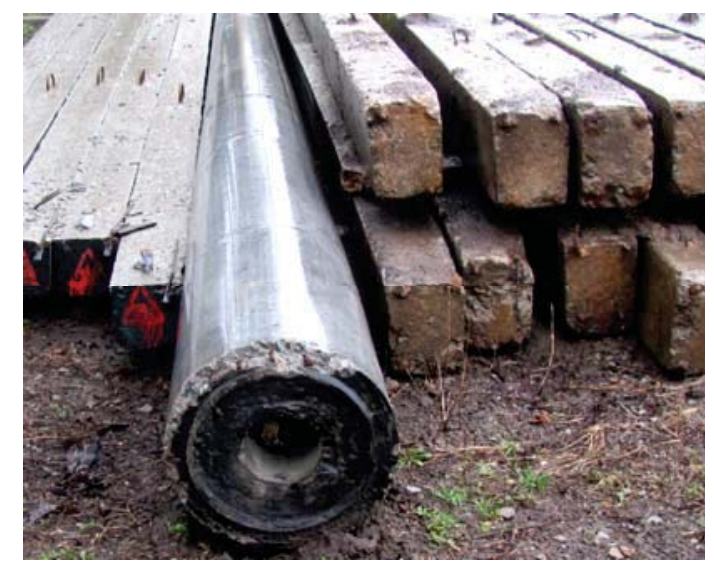

a)

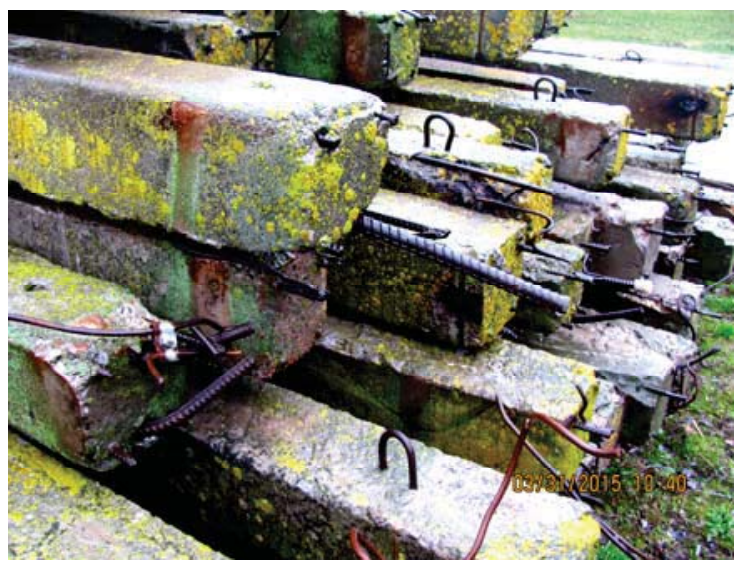

B)

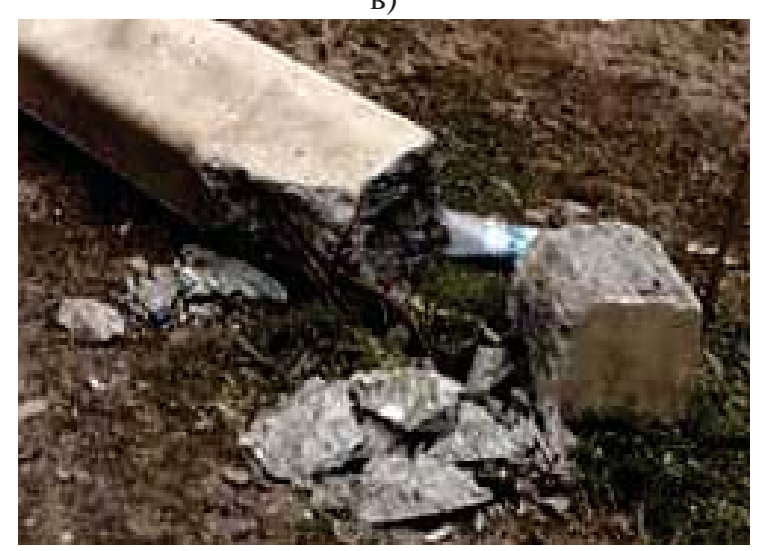

д)

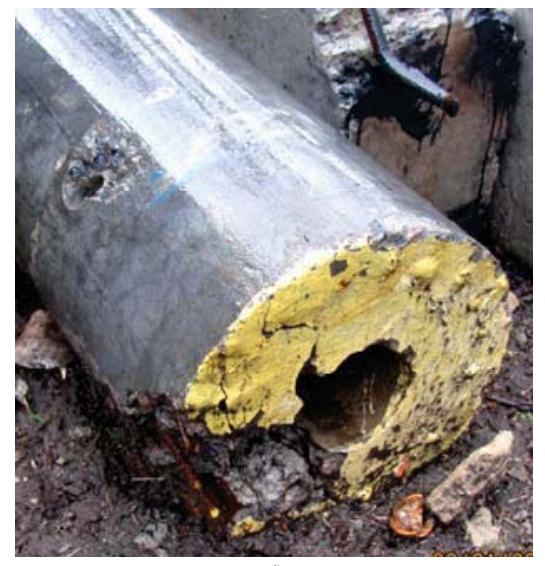

б)

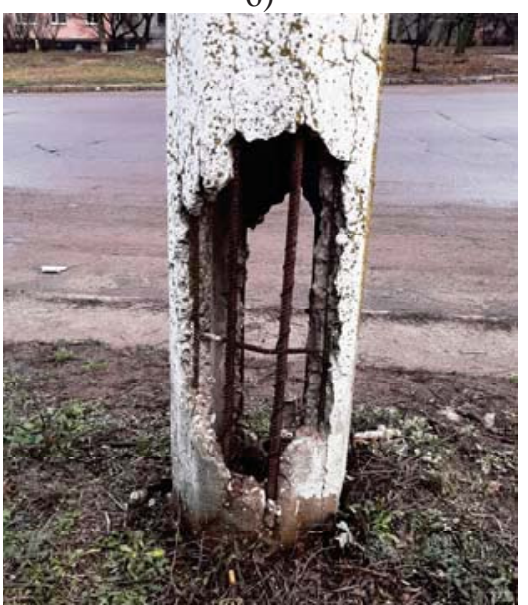

Г)

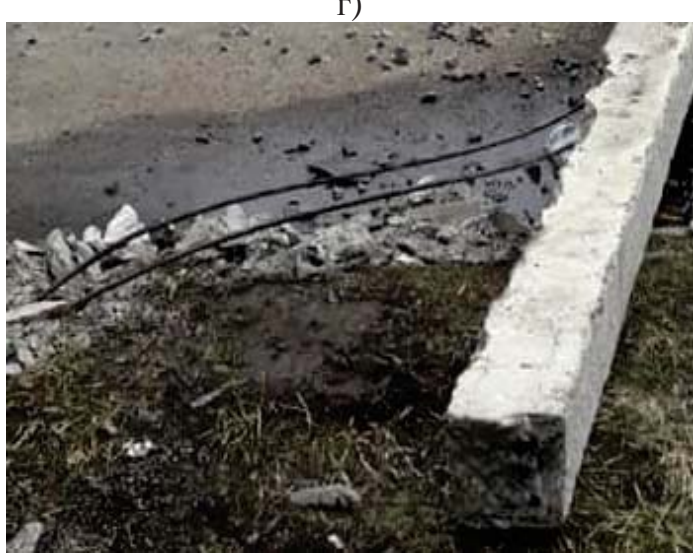

e)

Рисунок 1 - Зовнішний вигляд досліджуваного об'єкта

Джерело: зафіксовано авторами 
Розпізнавання образів (об'єктів, сигналів, процесів) - завдання ідентифікації об'єкта за його полем та іншими характеристиками, наприклад, - розпізнавання локальних ділянок опори, у яких є дефекти, за результатом вимірювання вносимих у вихорострумовий перетворювач (ВСП) опору $R_{\text {вн }}$ та індуктивності $L_{\text {вн }}$.

Нейро-нечітке моделювання проводили 3 використанням середовища MATLAB та його пакету Fuzzy Logic Toolbox (нечітку модель типу Сугено, для налаштування використано гібридний алгоритм) [5].

В якості вхідних та вихідних параметрів розглянемо детерміновані та ймовірнісні ознаки.

До детермінованих ознак, що мають конкретні постійні числові значення, належать:

$x_{11}$ - частота електромагнітного поля $f=10^{3} \ldots 10^{6}$ Гц;

$x_{12}$ - електропровідність армуючого стрижня опори $\sigma \approx 10^{6} \mathrm{CM} / \mathrm{M}$;

$x_{13}$-магнітна проникність стрижня $\mu \approx 10^{3}$;

$x_{14}$-діаметр стрижня $D=8 ; 10 ; 12 ; 14$ мм;

$y_{1}=F_{1}\left(x_{11}, x_{12}, x_{13}, x_{14}\right)$ - геометрія та розміри ВСП.

Ймовірнісні ознаки розпізнавання - це характеристики об'єкта, що мають випадковий характер:

$x_{21}$ - відхилення траєкторії сканування від осі арматури (причини - невидимість контрольованого стрижня, швидке сканування нерівної поверхні тощо);

$x_{22}$ - шар бетону (фарби) завтовшки $\delta=10^{-3} \ldots 10^{-2}$ м (причини - різні умови виробництва);

$x_{23}$ - швидкість сканування $(v=0,01 \ldots 1 \mathrm{~m})$;

$x_{24}$-розмір (розкриття) тріщини $T(T=0,1 \ldots 4$ мм, причини - різна степінь руйнування);

$x_{25}$ - координата $z$ розташування дефекту по висоті опори $(z=0 \ldots 1,5 \mathrm{~m})$;

$y_{2}=F_{2}\left(x_{21}, x_{22}, x_{23}, x_{24}, x_{25}\right)$ - середнє значення потужності сигналу ВСП від дефекту (причина - електронні шуми в тому самому радіодіапазоні).

Вихідний сигнал нейрону (виявлення дефекту) $Y$, який інтегрує в собі 9 характеристичних ознак:

$$
Y=F_{Y}\left(y_{1}, y_{2}\right)=F_{Y}\left(x_{11}, x_{12}, x_{13}, x_{14}, x_{21}, x_{22}, x_{23}, x_{24}, x_{25}\right) .
$$

Якщо ж з'ясовується, що опора має дефект, потрібно визначити тип цього дефекту та розмір $T$.

Гібридна нейронна мережа, структура якої показана на рис. 2, має 4 шари нейронів. Корегування правил виконувалось із застосуванням гібридного алгоритму, що є комбінацією методу зворотного розповсюдження помилки та методу найменших квадратів.

Для розпізнавання образу дефекту (ОД) потрібна база еталонних зразків. Навчання мережі проводили з використанням зразків штучних дефектів типу наскрізна тріщина $T$. Кожен ОД був отриманий під час зміни ряду параметрів контролю: частоти збудження ВСП від 1 кГц до 1 МГц, зазору $h$ між ВСП і поверхнею металу, відповідно до товщини бетонної оболонки, - від 1 до 10 мм, розмір (розкриття) тріщини ( $T=0,1 \ldots 4$ мм), координати розташування ВСП відносно дефекту (рис. 3 ).

Експериментальні вимірювання вносимих у ВСП опору $R_{\text {вн }}$ та індуктивності $L_{\text {вн }}$ проводили із використанням автоматичного мостового вимірювача імітансу E7-25 (рис. 3) з класом точності 0,15 на частотах $1 \ldots 1000$ кГц. В процесі сканування зразків арматури 3 наскрізною тріщиною $T$ аналізували всю модуляційну характеристику 
відносних значень активного $R_{\mathrm{BH}} / 2 \pi f L_{0}=F(z)$ та індуктивного $L_{\mathrm{BH}} / L_{0}=F(z)$ опорів. Графіки залежностей $R_{\text {вн }} / 2 \pi f L_{0}=F(z)$ і $L_{\text {вн }} / L_{0}=F(z)$ для різних $h, T, f$ показані в [3].

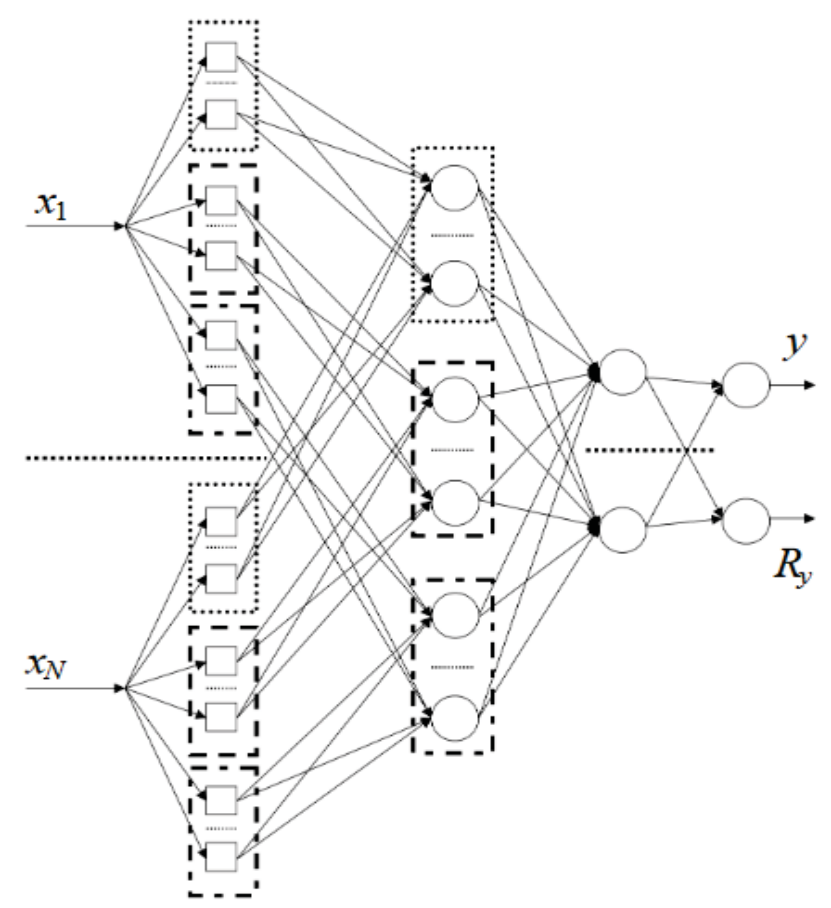

Рисунок 2 - Структура досліджуваної моделі на основі нейро-нечіткого моделювання (архітектура ANFIS)

Джерело: розроблено авторами

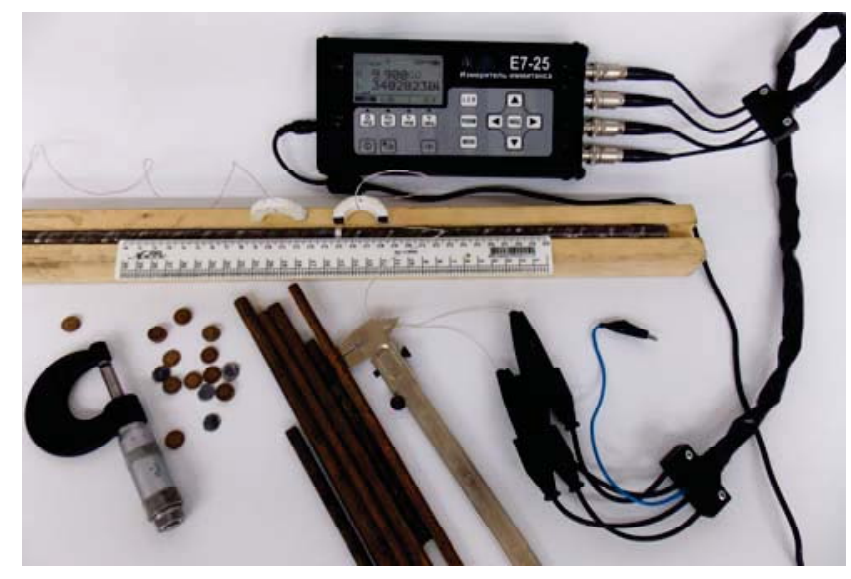

Рисунок 3 - Фізична модель об'єкту досліджень (арматурина $D=10$ мм з тріщиною $T=4$ мм) Джерело: власна розробка авторів

Коректність навчання мережі забезпечена шляхом розподілу експериментальних даних на тестові та навчальні. Для результативного моделювання було використано 2 блоки даних: обсяг навчальної вибірки становив 180 наборів даних та 60 наборів тестових. Інформаційні блоки заповнювали із врахуванням особливостей нейромережевого синтезу - дані повинні змінюватись почергово (в бік зростання) та максимально насичено заповнювати всю область їхніх значень. Для навчання мережі використано гібридний методом навчання з рівнем похибки 0 та кількістю циклів 400.

Після завершення навчання нейро-нечіткої мережі було виконано аналіз показників якості класифікації (точність, чутливість, помилки першого та другого 
роду) та залежності похибки навчання від кількості циклів навчання, що підтвердив працездатність мережі.

Синтезовано електромагнітну систему діагностування дефектів опор повітряних ЛЕП із використанням нейро-нечіткого моделювання, яка складається 3 наступних блоків (рис. 4):

1) блок зчитування початкових даних (первинний ВСП - контроль можна реалізувати за внесеними $R_{\mathrm{BH}}$ та $L_{\mathrm{BH}}$ );

2) блок попередньої обробки даних, видалення шумів і спотворень сигналу, приведення даних у формат, що якнайкраще дозволяє робити точне перетворення в подальшому блоці (вторинний автогенераторний перетворювач та АЦП - контроль можна здійснювати за амплітудою і фазою напруги на резонансному контурі);

3) блок нейромережевої обробки, який на основі відповідним чином підготовлених даних, що поступають в нього, чинить ідентифікацію дефекту;

4) блок кінцевого перетворення, який чинить зворотне перетворення даних у формат, придатний для розгляду персоналом, забезпечує наочне представлення даних діагностики про стан об'єкту, придатне для ухвалення управлінських рішень щодо ремонтно-відновлювальних робіт або заміни опори.

Подальша обробка даних здійснюється користувачем, в завдання якого входить вибір діагнозу відповідно до рекомендацій, що надає нейромережева частина, а також верифікація отриманого сигналу за критерієм логічної відповідності розвитку реальної ситуації, що дозволяе додатково збільшити надійність контролю. Вибір діагнозу здійснюють за чотирма нечіткими термами: "справний", працездатний", "обмежено працездатний" та "аварійний" у відповідності до класифікації технічного стану металевих конструкцій [6].

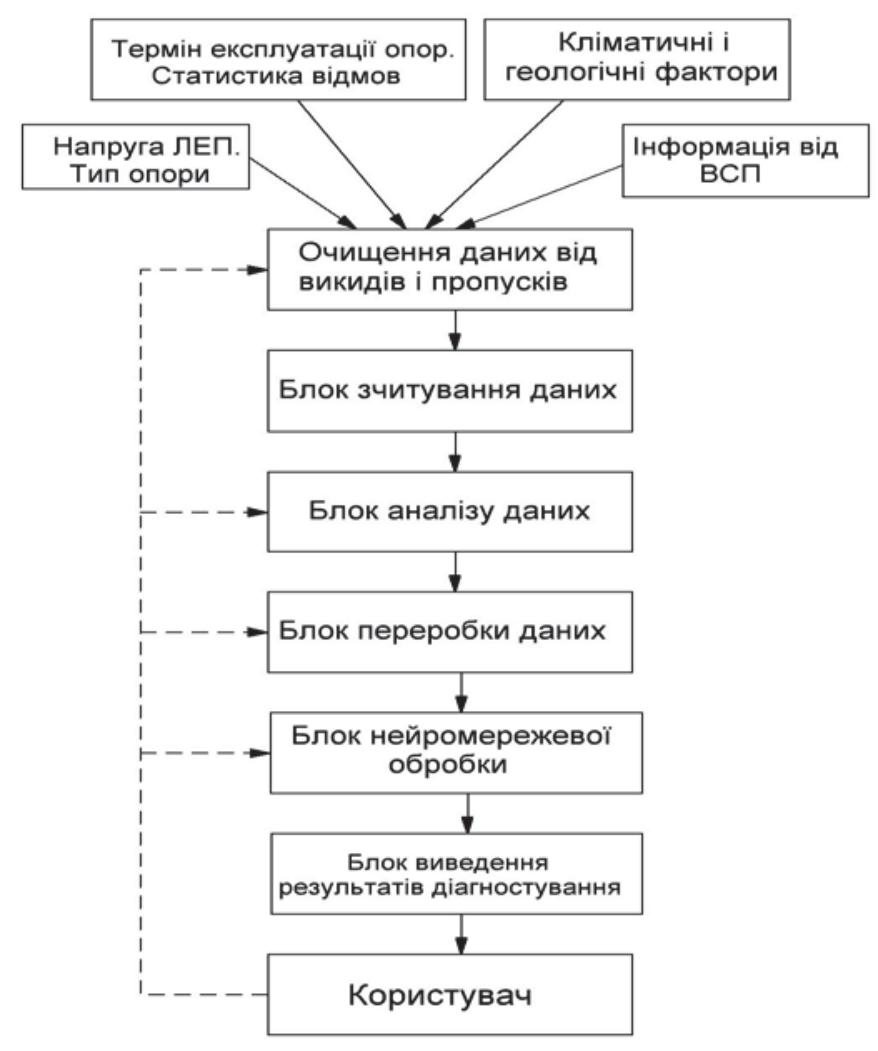

Рисунок 4 - Структура електромагнітної нейромережевої системи діагностування Джерело: розроблено авторами 
Структура електромагнітної системи діагностики показана на рис. 4. Вхідні дані для діагностики - напруга ЛЕП, тип опори, термін експлуатації, статистика відмов, дані про кліматичні і геологічні умови, сигнал з ВСП. Крім того, можливе введення додаткових даних від користувача тощо.

\section{Висновки.}

1. Аналіз причин аварійних ситуацій елементів ЛЕП показав, що $30 \ldots 35 \%$ становлять пошкодження залізобетонних опор, a існуючі методи неруйнівного діагностування стану арматури та несучої спроможності опор недостатньо дієві. Це вимагає удосконалення безконтактного електромагнітного методу контролю.

2. Дослідження комплексу характеристичних параметрів дозволило обрати 9 найбільш інформативних детермінованих та ймовірнісних ознак образу дефекту.

3. Навчання нейронної мережі проведено з використанням зразків штучних дефектів типу наскрізна тріщина арматури за гібридним методом навчання з рівнем похибки 0 та кількістю циклів 400, що дозволило підвищити якість розпізнавання образу дефекту.

4. Поєднання переваг електромагнітної системи діагностування дефектів із використанням нейро-нечіткого моделювання дозволить істотно збільшити швидкодію вихрострумового контролю та надійність розпізнавання дефектів опор.

\section{Список літератури}

1. Національна комісія, що здійснює державне регулювання у сферах енергетики та комунальних послуг (НКРЕП). Звіт про результати діяльності НКРЕП у 2018 рочі: веб-сайт. URL: https://www.nerc.gov.ua/?id=39678 (дата звернення: 20.12.2019).

2. Приборы для неразрушающего контроля материалов и изделий: справочник / за ред. В.В. Клюева. Москва : Машиностроение, 1986. 488 с.

3. Бондаренко В.Б. Проблеми електромагнітної дефектоскопії опор повітряних ліній електропередачі. Проблеми енергоефективності та автоматизації в промисловості та сільському господарстві: зб. матеріалів конф. XI-ї Міжн. наук.- практ. конф., Кіровоград, 21-22 жов. 2015 р. Кіровоград: КНТУ, 2015. С. 112-114.

4. Бондаренко В.Б. Підвищення надійності та продуктивності вихорострумової діагностики елементів повітряних ЛЕП. Енергоефективність: наука, технології, застосування: зб. тез доп. всеукр. наук.- практ. конф., Київ, 27 листопада 2019 р. Київ: НПУ імені М.П. Драгоманова, 2019. C. 8-11.

5. Леоненков, А.В. Нечеткое моделирование в среде MATLAB и fuzzyTECH : книга. СанктПетербург : БВХ, 2005. 736 с.

6. ДСТУ Б В.2.6-210:2016. Оценка технического состояния эксплуатируемых стальных строительных конструкций. [Чинний від 2017-01-01]. Київ: Мінрегіон України, 2016. 57 с. (Національний стандарт України).

\section{References}

1. Sait «Nacional`na komisiya, shho zdijsnyuye derzhavne regulyuvannya u sferax energety`ky` ta komunal`ny`x poslug» [Site of National Commission for State Regulation of Energy and Utilities]. nerc.gov.ua. Retrieved from https://www.nerc.gov.ua/?id=39678 [in Ukrainian].

2. Klyuev, V. (Eds.). (1986). Priboryi dlya nerazrushayuschego kontrolya materialov i izdeliy [Devices for non-destructive testing of materials and products: a reference]. Moscow: Mashinostroenie [in Russian].

3. Bondarenko, V.B. (2012). Problemy` elektromagnitnoyi defektoskopiyi opor povitryany`x linij elektroperedachi [Problems of electromagnet defectoscopy poles of repeated transmission lines]. Problems of energy efficiency and automation in industry and government: XI Mezhdunarodnaia nauchnoprakticheskaia konferentsiia (21-22 zhovtnya 2015 r.) - 21-st International Scientific and Practical Conference. (pp. 112-114). Kirovograd: KNTU [in Ukrainian].

4. Bondarenko, V.B. (2019). Pidvy`shhennya nadijnosti ta produkty`vnosti vy`xorostrumovoyi diagnosty`ky` elementiv povitryany`x LEP [Improvement of reliability and performance of eddy current diagnostics of air transmission line elements]. Energy efficiency: science, technology, application: Vseukrayins`ka nauchnoprakticheskaia konferentsiia (27 ly`stopada 2019 r.) - All-Ukrainian Scientific 
and Practical Conference. (pp. 8-11). Ky`yiv: NPU imeni M.P. Dragomanova[in Ukrainian].

5. Leonenkov, A.V. (2005). Nechetkoe modelirovanie v srede MATLAB i fuzzyTECH [Fuzzy modeling in MATLAB and fuzzyTECH]. Sankt-Peterburg: BVH [in Russian].

6. DSTU B V.2.6-210:2016. Otsenka tehnicheskogo sostoyaniya ekspluatiruemyih stalnyih stroitelnyih konstruktsiy. [National Standard B V.2.6-210:2016. Assessment of the technical condition of operating steel building structures]. Kyiv, Minregion Ukrai'ny, 2016. 57 p. [in Ukrainian].

Vladimir Bondarenko, Post-graduate, Kateryna Petrova, Assoc. Prof., PhD tech. sci., Sergiy Serebrennikov, Prof., PhD tech. sci.

Central Ukrainian National Technical University, Kropyvnytskyi, Ukraine

\section{Synthesis of an Electromagnetic System for the Diagnosis of Defects of Air Transmission Lines Using Neuro-fuzzy Modeling}

The purpose of the work is to develop a system for diagnosing defects (damages of the armature) of air transmission line supports based on the combination of electromagnetic control principles with the interpretation of the results of diagnosis using neuro-fuzzy modeling. It is shown that in the case of uncertainty in the diagnosis of defects of air transmission line supports in real time, it is rational to build an electromagnetic system using neuro-fuzzy modeling. Practice shows that the bars of the reinforcement bars of the transmission lines support fractures oriented perpendicularly forming, and stress-corrosion cracks - parallel to it. Optimal results of the electromagnetic control are achieved in the scan direction, which intersects the defects perpendicular to their long side. In the case of electromagnetic diagnosis, the conclusion about the defect and its size is usually based on the values of the amplitude, phase and frequency of the current signal. However, the large amount of information that comes from controlling the tens and hundreds of power lines in the field under live conditions exceeds the human ability to adequately perceive it in real time and requires automation of data analysis; this will significantly increase the speed of control, reduce errors and errors associated with the actions of the staff, will allow to coordinate the results to the object of control. Under such conditions, it is rational to synthesize an electromagnetic system for diagnosing defects of air transmission lines using neuro-fuzzy modeling. That is, create a neural network and teach it to look for defects based on real data. The most informative deterministic and probable signs of defect image are considered. It is proved that the use of hybrid neural networks leads to a significant increase in the speed of eddy current control and the reliability of recognition of defects.

An analysis of the causes of emergency situations of the transmission line elements showed that 30-35\% are damage to reinforced concrete supports, and the existing methods of non-destructive diagnosis of the condition of reinforcement and bearing capacity of the supports are not effective enough. This requires improvement of the non-contact electromagnetic control method. The study of the complex of characteristic parameters allowed us to select the 9 most informative deterministic and probabilistic features of the defect image. The training of the neural network was carried out using samples of artificial defects such as throughthrough fracture of the reinforcement according to the hybrid method of training with the error level 0 and the number of cycles 400, which allowed to improve the quality of recognition of the defect image. The correctness of network training is ensured by dividing the experimental data into test and training ones. For data modeling, 2 data blocks were used: the training sample volume was 180 datasets and 60 test sets. The information blocks were filled taking into account the features of neural network synthesis - the data should change alternately (in the direction of growth) and as much as possible fill the entire area of their values.

Diagnostic inputs include transmission line voltage, resistance type, lifetime, failure statistics, climatic and geological conditions, VCT signal. It is also possible to enter additional user data and more. Combining the benefits of an electromagnetic defect diagnosis system with the use of neuro-fuzzy modeling will significantly increase the speed of eddy current control and the reliability of recognition of defects of supports.

defects of supports, eddy current control, neuro-fuzzy modeling, diagnostics 